\title{
Review on Corporate Bond Research
}

\author{
Jiemin Huang \\ Shenzhen Institute of Information Technology \\ 2188 Longxiang Boulevard, Longgang District, Shenzhen Shenzhen City \\ People's Republic of China, 086-518172 \\ huang_jiemin819@126.com
}

\begin{abstract}
The paper analyzes literatures on Chinese corporate bond research in China, mainly on several points below: firstly, comparative study on Chinese corporate bond and American corporate bond; secondly, research on credit spread of corporate bond; thirdly, research on liquidity risk of corporate bond and risk management; fourthly, research on structuring pricing model of corporate bond; in the end, research on term structure of interest rates of corporate bond. There are some researches on yield spread to maturity of corporate bond in China, but, I find that there are few research on taxes effect of yield spread to maturity of corporate bond.
\end{abstract}

Keywords-corporate bond; yield spread; term structure of interest rates

\section{INTRODUCTION}

In China, there are three different supervisors of corporate bond, and the first is NDRC (National Development and Reform Commission). According to "Corporate bond control regulations" which is formulated by the State Council and notifications issued by NDRC, it governs issuance of state owned enterprises, which including central enterprises and enterprises invested or guaranteed by state government. The enterprises collect money to the national key construction projects or local infrastructure construction, such as highway, railway, hospitals, schools and city infrastructure construction, and so on. In 1985, Shenyang real estate development Co., LTD issued the first corporate bond in China.

The second supervisor is CSRC (China Securities Regulatory Commission), and it is in charge of examining and approving public companies, and the money collected is used for reinvestment and purchase fixed assets. In August 2007, CSRC formulated "Corporate bond to distribute Experiment site Means" according to reformulated "Securities Law" and "Company Act", and the corporate bond market in Stock Exchange begins.

The third supervisor is the Chinese inter-bank market dealers association which is governed by People's Bank of China and it mainly does non-financial business financing, and the business could decide itself about how to use the collected money. Financing vehicles are also known as interim bills. In April 2008, according to "Non-financial business debt financing tool management approach of the Market of bond among the bank", the Chinese inter-bank market dealers association examines and approves issuance of corporate bond of non-financial business. [1]

In China, literatures on corporate bond researches are mainly about: comparative study on Chinese corporate bond and American corporate bond; research on credit spread of corporate bond; research on liquidity risk of corporate bond and risk management; research on structural pricing model of corporate bond; research on term structure of interest rates of corporate bond.

\section{REVIEW OF COMPARATIVE STUDY ON CHINESE CORPORATE BOND AND AMERICAN CORPORATE BOND}

Gao Xiaoqiang analyzed the differences of Chinese security market and American security market from six aspects, such as the kinds and term of securities, issuance bodies, investors, markets, credit ratings and management systems. [2] US has well developed corporate bond markets, and it has various securities, including mortgage bonds, debenture bonds, convertible bonds, with the authentication of equity securities, redeemable bond, floating rate bond and high yield bonds. While in China, there are a few kinds of corporate bonds, and we don't have high yield bonds till now.

The issuance bodies in US includes large scale companies with good credit, and this kind of corporates issue credit bonds, and some small companies issue high yield bonds to solve the problem of shortage of funds, and boost the economic development in US. In China, the issuance bodies are huge state owned enterprises, the local government guarantee company, and big public companies, and these companies have good credit and issue credit bonds, but small companies hardly could issue bonds to collect money. This restricts development of small companies and it's bad for economic development in China[10-13].

On the aspect of investors, corporate bond investors in US are banks, insurance companies, pension funds, saving institutions and other kinds of institutions and personal investors is $5 \%$ of all. In China, the investors of corporate bond are commercial banks, insurance companies, fund corporates and security companies, etc. We don't use pension funds to invest in corporate bonds yet[13-16].

On the aspect of market services, American bond market is well developed, all the bonds are issued publicly, and mainly by means of OTC exchange. In China, bond markets include interbank bond market and stock exchange. Interbank bond market adopts internal exchange, and it's the main exchange method of corporate bond[1621].

On the aspect of credit rating, credit rating in US has developed for a century, and it's perfect. Rating agencies are independent, authoritative, such as Moody, Standard 
and Poor's, and so on, and they provide investors with good directions. In China, rating agencies are small, dependent on government and recusant, and also rating narrow range[21-25].

On the aspect of management system, Federal government of the United States, States, The Securities Industry Association formulate relevant law and regulations, including "Federal Securities Act", "Securities Exchange Act", "Investment Company Act", "Investment Advisers Act of", "insider trading Act", "The government securities law", "Trust contract law", "Securities Investor Protection Act" and "Bank Holding Company Act" etc. Law and regulations on bond in China are increasingly improved, but still need to be further perfected[26-30].

\section{REVIEW ON CORPORATE BOND CREDIT SPREAD RESEARCH}

Credit spread means that corporate bond and treasury bond have the same residual maturity and cash flow, and the yield to maturity of corporate minus the yield to maturity of treasury bond[31]. The reason that credit spread exists is that a higher default risk of corporate bond, and when invest corporate bond, investors expect higher yield to maturity to make up for risks. Zhang Ran take corporate bond as research subject, and in the assumption of no arbitrage he inferred the relation between credit spread and economy development.[4] He used bond market data and data of consumption, investment, production, export to examine the model, and found the ability of credit spread of corporate bond to forecast and explain macroeconomy. The results show that credit spread could perfectly predict and explain consumption, export, investment, Industrial value increases and inflation. And credit spread could provide better macro-economy information than term of interest rate.

Sun Ke applied GARCH model to find the macro and micro factors of corporate bond credit spread with different terms, and curvature, slope of curve of treasury bond yield, inflation rate and exchange rate have important effect on corporate bond credit spread. [3] The results show that there is negative relation between corporate bond credit spread and short term interest rate. On the other hand, stock market has important effect on corporate bond credit spread, when the stock market is partial hot, bond demand would decrease, and credit spread would increase. Also, exchange rate has effect on corporate bond credit spread, and when RMB appreciates, export decreases, income decreases, corporate bond default risk increases, and credit spread increases.

Liu Guoguang researched on the relation between public corporate bond credit spread of Shenzhen and Shanghai stock market and treasury bond yield, and found that they have significant co-integration relationship, and there is a long-term equilibrium relationship. [5]

\section{RESEARCH ON LIQUIDITY RISK OF CORPORATE BOND AND RISK MANAGEMENT}

Hong Baozhen built five factors model which includes turnover rate, slope, credit, bond credit rating and maturity, and analyzed recent data from Shenzhen and Shanghai stock exchange, and analyzed different corporate bond liquidity premium. [6] And the results show that the stronger the liquidity, the smaller the liquidity risk premium. Corporate bond liquidity differences in China are small.

Investment to corporate bond has some risks, according to risk diversification theory, the bond portfolio yield is a weighted average of bond yields. There are several methods to effectively avoid risk and maximize the yields. Firstly, terms scattered method, that is invest to different maturities corporate bonds. Secondly, regional scattered method, that is invest to different corporates in different areas, and decrease the risk of economy recession of some districts. Thirdly, industry scattered method, invest to different industry, because some industry's corporate bond spread would decrease as the natural conditions and consumer demands changes, etc.

\section{RESEARCH ON STRUCTURING PRICING MODEL OF CORPORATE BOND}

Liu Weijing corporate bond pricing problems in the condition that corporate debt obeys continuous diffusion process, on the basis of corporate asset valuation obey the double exponential jump diffusion process. [7] First of all, giving the corporate bond pricing analytic solutions based on zero coupon bonds by means of unit pricing method on the simple condition. Then, giving default probability of corporate bond pricing problem on common condition, and discuss term structure of credit spread. The empirical analysis show that the model could fit actual situation well.

Zhou Xiaokun used structured pricing model for empirical analysis of bond market in US and China, and found that the spread from the model is far smaller than the real spread. [8] There are two possible reasons, on the one hand, using the pay date of bond interest which has certain maturity date to substitute zero coupon bond in Merton model and perpetual bond in Leland model. On the other hand, Structural Models are based on claim theory, because he only considered default risk and ignored other factors that have effect on the bond spread, so he underestimate market spread. And he didn't consider liquidity, taxes and system risks.

\section{RESEARCH ON TERM STRUCTURE OF INTEREST RATES OF CORPORATE BOND}

Gao Yijie found that corporate bond yield in China complied with the term structure of interest rates expectations theory in some extent by empirical analysis. [9] There is a long-term equilibrium relationship between long-term interest rates and short-term interest rates. But the expected transmission effects among different term structures are not strong, and this reflects that the corporate bond markets in China are not perfect, and there is quite severe short-term speculation.

\section{REVIEW}

Literatures on corporate bond research are in five directions: comparative study on Chinese corporate bond and American corporate bond; research on credit spread 
of corporate bond; research on liquidity risk of corporate bond and risk management; research on structuring pricing model of corporate bond; in the end, research on term structure of interest rates of corporate bond.

These researches made great achievements, but also have some lacks. There are few researches on taxes effect on corporate bonds. According to scholars, the reasons of spread of yield to maturity between corporate bonds and treasury bonds are credit risk, default risk and system risks, etc. But they ignore state taxes and national taxes and it's a most important factor, and we need further research on it.

\section{REFERENCES}

[1] Hong Yanrong, Bull supervision, path dependence and future development frame of corporate bond, Securities Market Herald, 2010.04

[2] Gao Xiaoqiang, Comparison and enlightenment of corporate bond market in US and China, New Finance, 2003

[3] Sun Ke, Research on factors of dynamic process of corporate bond credit spread, Securities Market Herald, 2010.07

[4] Zhang Ran, Credit spread change and Chinese entities economic growth expectations, Securities Market Herald, 2010.10

[5] Liu Guoguang, Wang Huimin, Research on dynamic relation between corporate bond credit spread and treasury yield rate, Journal of Shanxi Finance and Economics University, Vol.27 No.5 Oct.,2005

[6] Han Baozhen, Empirical research on corporate bond liquidity premium in China, Vol.28 No.6, Dec. 2010

[7] Liu Weijing, Zhou Shengbin, Corporate bond pricing based on Index jumped diffusion process, economic mathematics, Vol.28, No.1 Mar.2011

[8] Zhou Xiaokun, Empirical analysis on structural models of corporate bond pricing, Social Scientist, No.4,General No.120 Jul., 2006

[9] Gao Yijie, Cointegration analysis based on corporate bond term stucture of interest rate in China, Theoretical Investigation, 2006.08

[10] Fisher L. Determinants of the risk premiums on corporate bonds[J]. Journal of Political Economy, 1959, 67: 217-237.

[11] Smidt S. Which road to an efficient stock market: Free competition or regulated monopoly[J]. Financial Analysts Journal, 1971. 27 (5): 18-69.

[12] Garman M. Market microstructure[J]. Journal of Financial Economics, 1976, 3: 257-275.

[13] Crabbe L.E, Turner C.M. Does the liquidity of a debt issue increase with its size? Evidence from the corporate bond and medium-term note markets[J]. Journal of Finance, 1995, 50(5): 1719-1734.
[14] Sarig O, Warga A.D. Bond price data and bond market liquidity[J]. Journal of Financial and Quantitative Analysis, 1989, 24 (3): $367-378$

[15] Amihud Y, Mendelson H. Liquidity, maturity, and the yields on US Treasury securities[J]. Journal of Finance, 1991, 46(4): 14111425.

[16] Alexander G.J., Edwards A.K., Ferri M.G. The determinants of trading volume of high-yield corporate bonds[J]. Journal of Financial Markets, 2000, 3: 177-204.

[17] Elton E.J., Gruber M.J., Agrawal D., Mann C. Factors affecting the valuation of corporate bonds[EB/OL]. http://pages.stern.nyu.edu/eelton/Research.htm, 2002

[18] Shulman J., Bayless M., Price K. Marketability and default influences on the yield premia of speculative-grade debt[J]. Financial Management, 1993, 22(3): 132-141.

[19] Gehr A.K., Martell T.F. Pricing efficiency in the secondary market for investment-grade corporate bonds[J]. Journal of Fixed Income, 1992, 2(3): 24-38.

[20] Jankowitsch R., Mosenbacher H., Pichler S. Measuring the liquidity impact on EMU government bond prices[EB/OL]. http://papers.ssrn.com/sol3/papers.cfm? abstract_id=302795, 2002

[21] Tychon P., Vannetelbosch V. Debt valuation and marketability risk[EB/OL]. http://www2.econ.ucl.ac.be/ Users/v.vannetelbosch/, 2002

[22] Maddala G. Limited Dependent and Quantitative Variables in Econometrics[M]. Cambridge: Cambridge University Press, 1983.

[23] Amihud Y. Illiquidity and stock returns: cross-section and timeseries effects[J]. Journal of Financial Markets, 2002, 5: 31-56.

[24] Kyle A.S. Continuous auctions and insider trading[J]. Econometrica, 1985, 53: 1315-1335.

[25] Swamy P. efficient Inference in a Random Coefficient Regression Model[J]. Econometrica, 1970, 38: 311-323.

[26] Hausman J., Taylor W. Panel Data and Unobservable Individual Effects[J]. Econometrica, 1981, 49: 1377-1398.

[27] Harvey A C. Forecasting, Structure Time Series Models and the Kalman Filter[M]. Cambridge University Press, 1989.

[28] Hamilton, James D. Time series Analysis[M]. Princeton University Press, 1994.

[29] Sun C. Variation of Federal Cost-share Programs in the United States and the Inducement Effects on Tree Planting[J]. Journal of Forestry Economics, 2007, 12(4): 276-296.

[30] Nejadmalayeri A., Singh M. Corporate taxes, strategic default, and the cost of debt[J]. Journal of Banking \& Finance, 2012, 36: 2900-2916.

[31] Jubinski D., Tomljanovich M. Do FOMC minutes matter to markets? An intraday analysis of FOMC minutes releases on individual equity volatility and returns[J]. Review of Financial Economics, 2013, 22: 86-97. 